Research Article

\title{
Method optimization for proteomic analysis of soybean leaf: Improvements in identification of new and low-abundance proteins
}

\author{
Rosilene Oliveira Mesquita ${ }^{1}$, Eduardo de Almeida Soares ${ }^{1}$, Everaldo Gonçalves de Barros ${ }^{2}$ \\ and Marcelo Ehlers Loureiro ${ }^{1}$ \\ ${ }^{1}$ Departamento de Biologia Vegetal, Universidade Federal de Viçosa, Viçosa, MG, Brazil. \\ ${ }^{2}$ Departamento de Biologia Geral, Universidade Federal de Viçosa, Viçosa, MG, Brazil.
}

\begin{abstract}
The most critical step in any proteomic study is protein extraction and sample preparation. Better solubilization increases the separation and resolution of gels, allowing identification of a higher number of proteins and more accurate quantitation of differences in gene expression. Despite the existence of published results for the optimization of proteomic analyses of soybean seeds, no comparable data are available for proteomic studies of soybean leaf tissue. In this work we have tested the effects of modification of a TCA-acetone method on the resolution of 2-DE gels of leaves and roots of soybean. Better focusing was obtained when both mercaptoethanol and dithiothreitol were used in the extraction buffer simultaneously. Increasing the number of washes of TCA precipitated protein with acetone, using a final wash with $80 \%$ ethanol and using sonication to ressuspend the pellet increased the number of detected proteins as well the resolution of the 2-DE gels. Using this approach we have constructed a soybean protein map. The major group of identified proteins corresponded to genes of unknown function. The second and third most abundant groups of proteins were composed of photosynthesis and metabolism related genes. The resulting protocol improved protein solubility and gel resolution allowing the identification of 122 soybean leaf proteins, 72 of which were not detected in other published soybean leaf 2-DE gel datasets, including a transcription factor and several signaling proteins.
\end{abstract}

Key words: proteomics; Glycine max, 2-DE, protein extraction, leaf proteome.

\section{Introduction}

Two-dimensional polyacrylamide gel electrophoresis (2-DE) is the most widely used method for comparison of quantitative changes in the protein proles of cells, tissues or whole organisms (Herbert et al., 2001). 2-DE is capable of resolving hundreds, and in some cases thousands, of proteins in a single separation procedure.

One of the major limitations of 2-DE methods in proteomics is the fact that low-abundance proteins are rarely seen in traditional 2-D maps, whilst most proteins in vivo are present at low abundance. These low-abundance proteins obviously perform very important roles and include transcription factors, signal transduction proteins and receptors. This limitation of 2-DE methods could be due either to the presence of overwhelming quantities of abundant soluble proteins which obscure the detection of lowabundance proteins or to the fact that these low-abundance

Send correspondence to Marcelo Ehlers Loureiro. Laboratório Fisiologia Molecular de Plantas, Departamento de Biologia Vegetal, Universidade Federal de Viçosa, Av. Peter Henry Rolfs s/n, Prédio do CCBII, $4^{\circ}$ andar, sala 418, 36571-000 Viçosa, MG, Brazil. E-mail: mehlers@ufv.br. proteins may not be completely solubilized prior to 2-DE. Efficient solubilization of protein samples is critical for high performance 2-D electrophoresis.

The most critical step in any proteomics study is protein extraction and sample preparation (Rose et al., 2004). Protein extraction methods can vary widely in reproducibility and representation of the total proteome. Better solubilization increases the separation and resolution of gels allowing identification of a higher number of proteins and more accurate quantification of differences in gene expression. Plant tissues, when compared to animal tissues, often contain lower protein concentrations and extraction is often rendered difficult by the presence of interfering compounds, such as secondary metabolites, phenolic compounds, lipids, nucleic acids, the cell wall and storage polysaccharides. Some of these compounds may interact with proteins and give poor resolution and high background in 2-DE gels. Phenol extraction methods have been developed to overcome some of these problems, but this method may reduce protein yield, is time consuming and requires the use of toxic phenol.

Several publications detailing soybean proteomics are available, with the majority of these publications ad- 
dressing changes in the proteome of seeds, roots, nodules and hypocotyls (Mooney et al., 2004; Hajduch et al., 2005; Wan et al., 2005; Natarajan et al., 2005, 2006; Djordjevic et al., 2007; Arai et al., 2008; Oehrle et al., 2008; Brechenmacher et al., 2009; Nanjo et al., 2010; Komatsu et al., 2010, 2011; Zhang et al., 2011). Some of these results are also contained in the Soybean Proteome Database (Sakata et al., 2009). Proteomic analyses of soybean leaf, on the other hand, are scarce. In the Soybean Database, only one gel is available, which presents poor resolution and sequencing of only 17 peptides (one peptide per spot) via Edman degradation. Krishnan and Natarajan (2009), using a phenol extraction method, have reported a fractionation technique using $10 \mathrm{mM} \mathrm{Ca}^{2+}$ and $10 \mathrm{mM}$ phytate to precipitate Rubisco from soybean leaf soluble protein extract, and identified only 52 proteins. Ahsan et al. (2010), using a TCA/acetone method, reported the identification of 54 proteins in leaves under heat stress, the majority of these proteins being chaperones.

No published work exists where different methods are compared or optimized for analysis of the leaf proteome in soybean, and despite the great number of proteins expressed in leaves, the results together do not allow identification of more than 100 proteins in this organ. Here we report an improved method for soybean leaf proteome analysis and the identification of 122 leaf proteins, 72 of which, based on published articles and the soybean proteomics web site, have not previously been detected in leaves.

\section{Material and Methods}

The TCA/acetone protein extraction method was chosen for optimization (Shen et al., 2002). Around $0.2 \mathrm{~g}$ of insoluble PVP (PVPP) was added to $1 \mathrm{~g}$ fresh weight of frozen leaves and this mixture was ground under liquid nitrogen. Immediately before thawing, $2 \mathrm{~mL}$ of a modified extraction buffer was added (Tris- $\mathrm{HCl} 40 \mathrm{mM}(\mathrm{pH} 7.5)$ $250 \mathrm{mM}$ sucrose, $10 \mathrm{mM}$ EDTA, 1\% Triton X-100, $1 \mathrm{mM}$ PMSF; $1 \mathrm{mM} \mathrm{DTT;} 2 \%$ (v/v) $\beta$-mercaptoethanol) and extraction was performed for $2 \mathrm{~h}$ at $4{ }^{\circ} \mathrm{C}$. Cellular debris was removed by centrifugation at $6,000 \times \mathrm{g}$ for $15 \mathrm{~min}$ at $4{ }^{\circ} \mathrm{C}$, and a second centrifugation of the supernatant was performed to completely remove any insoluble components. The precipitation of soluble proteins was performed by adding trichloroacetic acid (TCA) to a final concentration of $10 \%(\mathrm{w} / \mathrm{v})$ in cold acetone for $16 \mathrm{~h}$ at $-20^{\circ} \mathrm{C}$. The protein pellet was harvested by centrifugation at $6,000 \times \mathrm{x}$ for 15 min at $4{ }^{\circ} \mathrm{C}$. The sediment was washed 4 times with cold acetone $(10 \mathrm{~mL}$ each), and a final wash with ethanol $80 \%$ was carried out to remove the excess acetone and to improve the further steps of solubilization of the pellet. The pellet was dried by vacuum centrifugation at room temperature, and re-suspended in a modified 2-DE buffer (7 M urea, $2 \mathrm{M}$ thiourea, 2\% CHAPS, $100 \mathrm{mM}$ DTT and 2\% IPG buffer ( $\mathrm{pH} 4-7$, ampholytes)). Complete solubilization was achieved by sonication with three pulses of $15 \mathrm{~s}$ at $1500 \mathrm{~Hz}$. Protein concentration was determined by the Bradford method (Bradford, 1976), using BSA to construct a calibration curve.

The first-dimension IEF was performed using $24 \mathrm{~cm}$ linear IPG strips ( $\mathrm{pH} 4-7)$ in the IPGphor system (GE Healthcare). All IPG strips were rehydrated for $16 \mathrm{~h}$ with $250 \mu \mathrm{L}$ of rehydration buffer (8 M urea, 2\% CHAPS, $0.5 \%$ ampholytes, $0.002 \%$ bromophenol blue) containing $1 \mathrm{mg}$ of protein. Voltage settings for IEF were $250 \mathrm{~V}$ for $1 \mathrm{~h}$, $500 \mathrm{~V}$ for $1 \mathrm{~h}$, followed by a gradient from $1000-7000 \mathrm{~V}$ until achievement of a total of $5.2 \mathrm{kVh}$, followed by running at $8000 \mathrm{~V}$ to achieve $40 \mathrm{kVh}$. The focused strips were either electrophoresed runned immediately on a 2-D gel or stored at $-80{ }^{\circ} \mathrm{C}$ until further use. For the 2-D gel electrophoresis, the gel strips were incubated with equilibration buffer 1 [50 mM Tris- $\mathrm{HCl}$ ( $\mathrm{pH} 8.8$ ), $6 \mathrm{M}$ urea, 30\% glycerol, $2 \%$ SDS, $0.002 \%$ bromophenol blue, $1 \%$ DTT] and equilibration buffer 2 [50 mM Tris- $\mathrm{HCl}(\mathrm{pH} 8.8), 6 \mathrm{M}$ urea, 30\% glycerol, $2 \%$ SDS, $0.002 \%$ bromophenol blue, $2.5 \%$ iodoacetamide] for 15 min each and subsequently placed onto $12.5 \%$ polyacrylamide gel $(26 \times 32 \mathrm{~cm})$ with a Trisglycine buffer system as described by Laemmli (1970). Strips were overlaid with agarose sealing solution $(0.25 \mathrm{M}$ Tris base, $1.92 \mathrm{M}$ glycine, $1 \% \mathrm{SDS}, 0.5 \%$ agarose, $0.002 \%$ bromophenol blue) using an Ettan Daltsix electrophoresis system (GE Healthcare). the initial 2D eletrophoresis setting was $5 \mathrm{~W}$ (constant and maximal $20 \mathrm{~mA}$ ), followed by a separation run for $6 \mathrm{~h}$ using $12 \mathrm{~W}$ per gel (constant and maximal $50 \mathrm{~mA}$ ). The 2D-PAGE gels were visualized by staining with colloidal Coomassie blue G-250 as described by Newsholme et al. (2000). The gels were fixed overnight in $50 \%$ ethanol and 3\% phosphoric acid and then washed three times for $30 \mathrm{~min}$ with distilled water. Gels were pre-stained for $1 \mathrm{~h}$ in 34\% methanol, $17 \%$ ammonium sulfate and 3\% phosphoric acid and then stained for 2 days in the same solution containing Coomassie blue G-250 $(0.066 \%)$. Image acquisition was done using an ImageScanner III (GE Healthcare) and images were analyzed using ImageMaster 2D Platinum v. 7 software (GE Healthcare).

Protein spots were excised from the stained gels and washed first with distilled water to remove ammonium sulfate and then with $50 \%$ acetonitrile containing $25 \mathrm{mM}$ ammonium bicarbonate to destain the gel plugs. The gel plugs were dehydrated with $100 \%$ acetonitrile, dried under vacuum, and then re-swollen with $20 \mu \mathrm{L}$ of $10 \mu \mathrm{g} / \mathrm{mL}$ trypsin (modified porcine trypsin, sequencing grade, Promega, Madison, WI, USA) in $25 \mathrm{mM}$ ammonium bicarbonate. Digestion was performed overnight at $37{ }^{\circ} \mathrm{C}$. The resulting tryptic fragments were extracted by sonication in $50 \%$ acetonitrile and 5\% trifluoroacetic acid. The extracts were dried and then dissolved in 50\% acetonitrile and $0.1 \%$ trifluoroacetic acid. 


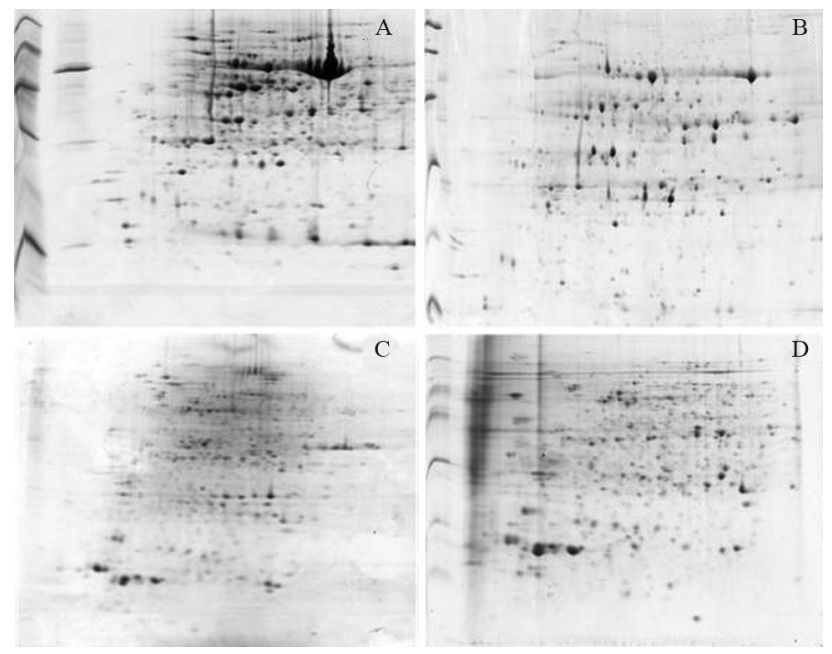

Figure 1 - 2-DE gel of protein from leaves and roots of soybean extracted using different methods. (A and C) - Leaf and root protein respectively extracted using the phenol-based method and (B and D) - Leaf and root protein respectively, extracted using the TCA/acetone method without modifications.

MALDI-TOF-MS analysis of tryptic peptides was performed using a Bruker UltraFlexIII spectrometer. Samples were co-crystallized with CHCA matrix and spectra acquired with 40 shots of a $337 \mathrm{~nm}$ nitrogen laser operating at $20 \mathrm{~Hz}$. Protein identification was done by searching the National Center for Biotechnology Information (NCBI) non-redundant database using the Mascot search engine and a probability-based scoring system (Perkins et al., 1999). The following parameters were used for database searches with MALDI-TOF peptide mass fingerprinting data: monoisotopic mass, $25 \mathrm{ppm}$ mass accuracy, trypsin as digesting enzyme with one missed cleavage allowed, carbamidomethylation of cysteine as a fixed modification, oxidation of methionine, $\mathrm{N}$-terminal pyroglutamic acid from glutamic acid or glutamine according to variable modifications.

For database searches with MS/MS spectra, the following parameters were used: average mass; 1.5 Da peptide and MS/MS mass tolerance; peptide charge of $+1,+2$ or +3 ; trypsin as digesting enzyme with 1 missed cleavage allowed; carbamidomethylation of cysteine as a fixed modification; oxidation of methionine, $\mathrm{N}$-terminal pyroglutamic acid from glutamic acid or glutamine according to variable modifications. For MALDI-TOF-MS data to qualify as a positive identification, a protein's score had to equal or exceed the minimum significant score (Perkins et al., 1999). Positive identification of proteins by MS/MS analysis required a minimum of two unique peptides, with at least one peptide having a significant ion score.

\section{Results and Discussion}

To evaluate the effect of the modifications to the TCA/acetone method, protein extractions were carried out using leaves and roots of soybean plants collected five weeks after germination. The phenol-base method (Wang et al., 2003), the original TCA/acetone method and the modified TCA/acetone method described here were tested using three biological replicates (three different extracts for each method from three different plants). An example of the 2-DE gels using $1 \mathrm{mg}$ protein extract is shown in Figure 1.

As evidenced in Figure $1 \mathrm{~A}$ and $\mathrm{C}$, the phenol-based method resulted in a higher level of subunits of the enzyme ribulose 1,5 bisphosphate carboxylase oxygenase (Rubisco). Furthermore, lower resolution was observed. This result is important for attempts to help improve the detection of low-abundance proteins in 2-DE gels of leaf protein. In leaves, Rubisco represents around $50 \%$ and $30 \%$ of total protein in $\mathrm{C} 3$ and $\mathrm{C} 4$ plants respectively (Feller et al., 2008). This high abundance hinders proteomic assessment of low-abundance proteins (Xi et al., 2006) and masks the ability of neighboring proteins to be detected (Corthalis et al., 2000; Shaw and Riederer, 2003; Cho et al., 2008). It also significantly limits the dynamic resolution of the gel (Herman et al., 2003). Krishnan and Natarajan (2009) described a method using a TCA/acetone extraction procedure together with a phytic acid treatment to deplete Rubisco in soybean leaf 2-DE gels. However, the number of proteins detected by these authors was in fact lower than that obtained when using the unmodified TCA/acetone method (511 spots versus 582 when using the phenol method). These results suggest that additional changes to the protocol, besides Rubisco depletion, are needed to increase the number of detectable proteins. In contrast to the situation with leaf tissue, the unmodified TCA/acetone method increases the number of spots detected in roots $(634$ spots using the phenol method versus 705). These differences support the inference that different sample preparation methods are required to produce optimal 2-DE results from different plant organs.

The effect of the modifications to the TCA/acetone method can be observed in Figure 2. A comparison between Figures $2 \mathrm{~A}$ and $2 \mathrm{~B}$ indicates that the modifications made to the TCA/acetone method improved both the solubilization of proteins and gel resolution, as indicated by the increase in spot number by $57 \%$ and $5.4 \%$ in leaf and root respectively (in leaves, 802 spots in modified method versus 511, and 743 to 705 in roots). No significant differences in the content of the large and small Rubisco subunits were observed with the modification of this method. These results ilustrate that significant increase in protein detection in 2D gels could be obtained by increase in solubilizatio besides no changes in Rubisco content. Particularly interesting is the increase in low molecular weight proteins in leaves resulting from the introduced modifications. These differences were reproducible and seen in all three repetitions for each method (data not shown). Effects of the modified method on the root proteome were also observed (Figures 


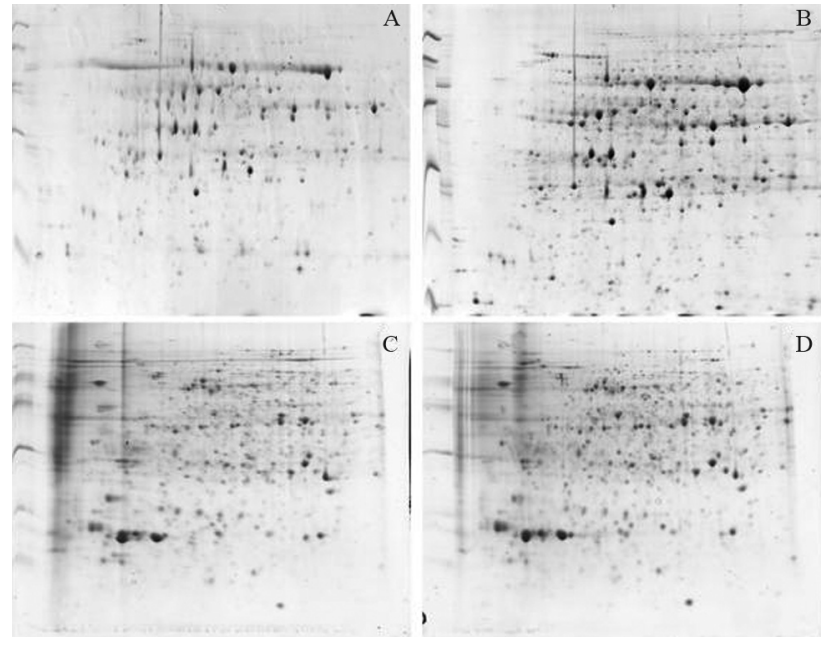

Figure 2 - Effect of modification of the TCA/acetone method on the resolution of 2-DE gels. (A and C) - Gels using protein extracted and prepared using the original TCA/Acetone method. (B and D) - Gels using protein extracted and prepared using the TCA/Acetone method with modifications. Extracts are from leaf (A and B) and root (C and D) tissue.
$2 \mathrm{C}, \mathrm{D})$, although the improvement was not as clear as that observed for leaf tissue. In roots, the number of spots also increased with the modifications made to the method, but the problem of low resolution in the region of low PI/higher molecular weight still remained, despite the improvement in resolution for higher $\mathrm{pI}$ proteins and the fact that more proteins were detected overall.

The improvements in the resolution of 2-DE gels for leaf tissue (Figure 3) were reflected by the successful identification of 122 proteins, based on the peptides matched in the NCBI protein bank, as described in Table 1. Figure 3 also shows that proteins coding for the large subunit of Rubisco are separated into several spots around the $53 \mathrm{KDa}$ region of the gels.

Although several additional proteins could potentially be identified, we used a Mowse score of 40 as a minimum confidence threshold for identification in this study. This score varied from 44 to 175 across identified proteins, with an average of 80 in this dataset (a score greater than

Table 1 - Proteins identified in the soybean leaf proteome using the proposed extraction method, with the number as indicated in protein map in Figure 3. MW/pI: theoretical protein molecular weight and isoelectric point. MO: MOWSE score; PM: number of peptides with matches in the PMF; SC: sequence coverage.

\begin{tabular}{|c|c|c|c|c|c|c|}
\hline Spot \# & NCBI closest homologue & $\mathrm{MW} / \mathrm{pI}$ & MO & $\mathrm{PM}$ & $\mathrm{SC}(\%)$ & Accession number \\
\hline 29 & Conserved hypothetical protein (Ricinus communis) & $37517 / 7.64$ & 70 & 11 & 31 & gi|223507406 \\
\hline 30 & Heat shock protein 70 (Cucumis sativus) & $75480 / 5.15$ & 164 & 16 & 25 & gi|1143427 \\
\hline 31 & Heat shock protein, putative (Ricinus communis) & $75431 / 5.35$ & 131 & 23 & 30 & gi|223534226 \\
\hline 32 & $\begin{array}{l}\text { Endoplasmic reticulum } \mathrm{HSC} 70 \text {-cognate binding protein precursor } \\
\text { (Glycine } \max \text { ) }\end{array}$ & $73822 / 5.15$ & 92 & 14 & 21 & gi|2642238 \\
\hline 33 & Calmodulin-2 (Glycine max) & $16878 / 4.11$ & 39 & 4 & 30 & calm2_soybn \\
\hline 35 & $\begin{array}{l}\text { Endoplasmic reticulum HSC70-cognate binding protein precursor } \\
\text { (Glycine max) }\end{array}$ & $73822 / 5.15$ & 88 & 15 & 23 & gi|218199537 \\
\hline 36 & Conserved hypothetical protein (Ricinus communis) & $37517 / 7.64$ & 72 & 12 & 37 & gi|223507406 \\
\hline 38 & Unknown (Zea mays) & $46413 / 8.48$ & 70 & 9 & 24 & gi|224029795 \\
\hline 50 & $\begin{array}{l}\text { Ubiquinol-cytochrome c reductase complex } 14 \mathrm{kDa} \text { protein (Zea } \\
\text { mays) }\end{array}$ & $14676 / 9.78$ & 59 & 7 & 45 & gi|195627658 \\
\hline 61 & Unnamed protein product (Vitis vinifera) & $82205 / 6.18$ & 68 & 15 & 21 & gi|157345364 \\
\hline 64 & Predicted protein (Micromonas pusilla CCMP1545) & $148047 / 8.96$ & 64 & 22 & 17 & gi|226460779 \\
\hline 66 & ATP synthase subunit alpha, chloroplastic & $10615 / 9.97$ & 76 & 6 & 71 & gi|115502358 \\
\hline 70 & Hypothetical protein (Vitis vinifera) & $25360 / 9.67$ & 48 & 5 & 28 & gi| 147857970 \\
\hline 71 & $\begin{array}{l}\text { Hypothetical protein SORBIDRAFT_09g004780 (Sorghum } \\
\text { bicolor) }\end{array}$ & $84711 / 5.68$ & 62 & 12 & 20 & gi|242089665 \\
\hline 78 & $\begin{array}{l}\text { Ribulose-1,5-bisphosphate carboxylase/oxygenase large subunit } \\
\text { (Falkia repens) }\end{array}$ & $52003 / 6.20$ & 204 & 19 & 43 & gi|21634087 \\
\hline 79 & ATP synthase CF1 beta subunit (Caulerpa taxifolia) & $14446 / 5.40$ & 60 & 8 & 52 & gi|219964549 \\
\hline 81 & $\begin{array}{l}\text { Ribulose-1,5-bisphosphate carboxylase/oxygenase large subunit } \\
\text { (Falkia repens) }\end{array}$ & $52003 / 6.20$ & 113 & 17 & 33 & gi|21634087 \\
\hline 95 & $\begin{array}{l}\text { Ribulose-1,5-bisphosphate carboxylase/oxygenase large subunit } \\
\text { (Chrysophyllum oliviforme) }\end{array}$ & $52005 / 6.14$ & 130 & 15 & 32 & gi|37194725 \\
\hline 100 & Hypothetical protein (Vitis vinifera) & $22800 / 5.50$ & 63 & 7 & 40 & gi|147776335 \\
\hline 109 & Alanine aminotransferase 2 (Glycine max) & $53863 / 5.42$ & 127 & 20 & 49 & gi|158122137 \\
\hline 112 & $\begin{array}{l}\text { Hypothetical protein SORBIDRAFT_01g013800 (Sorghum } \\
\text { bicolor) }\end{array}$ & $25399 / 9.32$ & 58 & 5 & 21 & gi|242033585 \\
\hline
\end{tabular}


Table 1 (cont.)

\begin{tabular}{|c|c|c|c|c|c|c|}
\hline Spot \# & NCBI closest homologue & $\mathrm{MW} / \mathrm{pI}$ & $\mathrm{MO}$ & $\mathrm{PM}$ & $\mathrm{SC}(\%)$ & Accession number \\
\hline 125 & Unknown (Zea mays) & $46413 / 8.48$ & 70 & 8 & 20 & gi|224029795 \\
\hline 126 & Predicted protein (Populus trichocarpa) & $42891 / 9.87$ & 56 & 8 & 28 & gi|224053192 \\
\hline 129 & Predicted: hypothetical protein isoform 2 (Vitis vinifera) & $23816 / 7.68$ & 60 & 7 & 38 & gi|225433648 \\
\hline 140 & $\begin{array}{l}\text { Ribulose-1,5-bisphosphate carboxylase/oxygenase large subunit } \\
\text { (Prunus armeniaca var. ansu) }\end{array}$ & $52018 / 6.63$ & 90 & 13 & 27 & gi|15987084 \\
\hline 143 & ATP synthase, beta subunit (Iphigenia indica) & $52668 / 5.16$ & 65 & 11 & 21 & gi|16943743 \\
\hline 144 & Glutamine synthetase precursor (Glycine max) & $47948 / 6.73$ & 92 & 13 & 39 & gi|13877511 \\
\hline 147 & Os07g0622700 (Oryza sativa (japonica cultivar-group) & $36403 / 8.51$ & 57 & 8 & 26 & gi|115473437 \\
\hline 147 & ATP synthase beta subunit (Schoepfia schreberi) & $30447 / 5.12$ & 70 & 10 & 31 & gi|14718214 \\
\hline 148 & Cytosolic glutamine synthetase GSbeta1 (Glycine max) & $39138 / 5.48$ & 76 & 9 & 30 & gi|125550665 \\
\hline 151 & Glutamine synthetase precursor (Glycine max) & $47948 / 6.73$ & 67 & 12 & 28 & gi|13877511 \\
\hline 161 & $\begin{array}{l}\text { Ribulose-1,5-bisphosphate carboxylase/oxygenase activase alpha } 2 \\
\text { (Gossypium hirsutum) }\end{array}$ & $46944 / 4.84$ & 80 & 11 & 30 & gi|78100212 \\
\hline 163 & Rubisco activase, chloroplast precursor (Vigna radiata) & $48042 / 7.57$ & 123 & 13 & 40 & gi|10720249 \\
\hline 165 & Rubisco activase, chloroplast precursor (Vigna radiata) & $48042 / 7.57$ & 123 & 13 & 40 & gi|10720249 \\
\hline 172 & Phosphoribulose kinase, putative (Ricinus communis) & $45221 / 5.83$ & 68 & 13 & 29 & gi|223541989 \\
\hline 174 & $\begin{array}{l}\text { Leucine-rich repeat receptor-like kinase At1g09970 (Arabidopsis } \\
\text { thaliana) }\end{array}$ & $36335 / 5.76$ & 68 & 9 & 24 & gi|62321062 \\
\hline 215 & $\begin{array}{l}\text { Ribulose-1,5-bisphosphate carboxylase/oxygenase large subunit } \\
\text { (Chionochloa acicularis) }\end{array}$ & $1851 / 5.91$ & 62 & 4 & 100 & gi|167782336 \\
\hline 216 & Conserved hypothetical protein (Ricinus communis) & $37517 / 7.64$ & 71 & 10 & 33 & gi|223507406 \\
\hline 222 & Ribosomal protein subunit 2 (Phelipanche arenaria) & $21334 / 9.32$ & 77 & 12 & 42 & gi|83745361 \\
\hline 228 & Conserved hypothetical protein (Ricinus communis) & $37517 / 7.64$ & 76 & 11 & 38 & gi|223507406 \\
\hline 234 & Predicted protein (Populus trichocarpa) & $43420 / 6.93$ & 89 & 11 & 26 & gi|224096552 \\
\hline 237 & Chloroplast translational elongation factor $\mathrm{Tu}$ (Oryza sativa) & $50551 / 6.05$ & 62 & 7 & 24 & gi $\mid 6525065$ \\
\hline 240 & Hypothetical protein OsI_12352 (Oryza sativa Indica Group) & $7143 / 10.25$ & 58 & 5 & 61 & gi|218193198 \\
\hline 254 & Conserved hypothetical protein (Ricinus communis) & $37517 / 7.64$ & 71 & 10 & 38 & gi|223507406 \\
\hline 259 & $\begin{array}{l}\text { Predicted: similar to thioredoxin-related protein isoform } 2 \text { (Vitis } \\
\text { vinifera) }\end{array}$ & $30695 / 8.09$ & 74 & 10 & 29 & gi|225440205 \\
\hline 265 & Aldehyde oxidase 1 (Lactuca sativa) & $151096 / 6.34$ & 80 & 13 & 10 & gi|84579422 \\
\hline 284 & Chain A, Wild-Type Pea Fnr & $35060 / 6.54$ & 77 & 14 & 36 & gi|4930123 \\
\hline 287 & $\begin{array}{l}\text { Ferredoxin—NADP reductase, chloroplastic; Short=FNR; Flags: } \\
\text { Precursor (Vicia faba) }\end{array}$ & $40838 / 8.70$ & 99 & 18 & 37 & gi|729479 \\
\hline 335 & $\begin{array}{l}\text { Ribulose-1,5-bisphosphate carboxylase/oxygenase large subunit } \\
\text { (Hypserpa nitida) }\end{array}$ & $52058 / 6.04$ & 132 & 19 & 31 & gi|229464412 \\
\hline 374 & Triosephosphate isomerase (Glycine max) & $27415 / 5.87$ & 145 & 14 & 53 & gi|77540216 \\
\hline 383 & Elongation factor 2 (EF-2) (Beta vulgaris) & $94708 / 5.93$ & 63 & 7 & 49 & $\mathrm{O} 23755$ \\
\hline 407 & $\begin{array}{l}\text { Hypothetical protein SORBIDRAFT_05g010323 (Sorghum } \\
\text { bicolor) }\end{array}$ & $46371 / 8.99$ & 63 & 11 & 38 & gi|242068295 \\
\hline 451 & Predicted protein (Populus trichocarpa) & $42891 / 9.88$ & 66 & 9 & 31 & gi|224053192 \\
\hline 452 & Hypothetical protein OsI_38632 (Oryza sativa Indica Group) & $12206 / 10.42$ & 44 & 5 & 45 & gi|125536931 \\
\hline 454 & Os02g0762300 (Oryza sativa (japonica cultivar-group)) & $41702 / 8.86$ & 64 & 6 & 18 & gi|115448847 \\
\hline 474 & PSII Oxygen-evolving enhancer protein 2 precursor & $19825 / 4.81$ & 75 & 12 & 35 & gi|16995778 \\
\hline 498 & Unknown (Picea sitchensis) & $18083 / 5.89$ & 59 & 5 & 34 & gi|116780837 \\
\hline 510 & Unknown (Zea mays) & $46413 / 8.48$ & 72 & 7 & 22 & gi|224029795 \\
\hline 602 & ATP synthase beta subunit (Utricularia biflora) & $51814 / 5.09$ & 98 & 13 & 25 & gi|7688411 \\
\hline 611 & AT5G50010 (Arabidopsis thaliana) & $31261 / 5.44$ & 57 & 7 & 26 & gi|227202838 \\
\hline 651 & Unnamed protein product (Arabidopsis thaliana) & $66243 / 4.95$ & 63 & 9 & 14 & gi|9294322 \\
\hline 656 & ATP synthase CF1 alpha subunit (Glycine max) & $55776 / 5.16$ & 127 & 18 & 37 & gi|91214148 \\
\hline
\end{tabular}


Table 1 (cont.)

\begin{tabular}{|c|c|c|c|c|c|c|}
\hline Spot \# & NCBI closest homologue & MW/pI & MO & PM & $\mathrm{SC}(\%)$ & Accession number \\
\hline 656 & Conserved hypothetical protein (Ricinus communis) & $37517 / 7.64$ & 68 & 11 & 35 & gi|223507406 \\
\hline 658 & ATP synthase CF1 alpha subunit (Glycine max) & $55776 / 5.15$ & 69 & 14 & 27 & gi $\mid 91214148$ \\
\hline 671 & $\begin{array}{l}\text { Ribulose bisphosphate carboxylase large subunit (Psoralea } \\
\text { aculeata) }\end{array}$ & $52062 / 6.04$ & 139 & 23 & 39 & gi|125991557 \\
\hline 683 & Methionine synthase (Glycine max) & $84401 / 5.93$ & 141 & 21 & 30 & gi|33325957 \\
\hline 684 & $\begin{array}{l}\text { Hypothetical protein SORBIDRAFT_04g004825 (Sorghum } \\
\text { bicolor) }\end{array}$ & $6932 / 9.30$ & 48 & 4 & 63 & gi|242060674 \\
\hline 688 & Conserved hypothetical protein (Ricinus communis) & $37517 / 7.64$ & 73 & 10 & 29 & gi|223507406 \\
\hline 689 & Ribulose-biphosphate carboxylase (Mangonia tweedieana) & $51846 / 6.05$ & 159 & 23 & 42 & gi|209417523 \\
\hline 691 & $\begin{array}{l}\text { Ribulose 1,5-bisphosphate carboxylase-oxygenase large subunit } \\
\text { (Rhynchosia minima) }\end{array}$ & $51975 / 6.14$ & 166 & 20 & 38 & gi|18157319 \\
\hline 725 & Conserved hypothetical protein (Ricinus communis) & $37517 / 7.64$ & 64 & 10 & 29 & gi|223507406 \\
\hline 732 & $\begin{array}{l}\text { Ribulose-1,5-bisphosphate carboxylase/oxygenase large subunit } \\
\text { (Croton yucatanensis) }\end{array}$ & $52205 / 6.09$ & 98 & 16 & 37 & gi|126166052 \\
\hline 793 & $\begin{array}{l}\text { Ubiquinol-cytochrome } \mathrm{c} \text { reductase complex } 14 \mathrm{kDa} \text { protein (Zea } \\
\text { mays) }\end{array}$ & $14676 / 9.78$ & 50 & 7 & 43 & gi|195627658 \\
\hline 799 & Hypothetical protein (Vitis vinifera) & $42045 / 7.58$ & 62 & 11 & 26 & gi|147797309 \\
\hline 807 & Unknown (Picea sitchensis) & $18942 / 6.30$ & 48 & 6 & 34 & gi|116792186 \\
\hline 809 & $\begin{array}{l}\text { PSII Oxygen-evolving enhancer protein 1, chloroplast precursor } \\
\text { (Pisum sativum) }\end{array}$ & $35100 / 6.25$ & 91 & 9 & 27 & gi|131384 \\
\hline 809 & Cytosolic malate dehydrogenase (Glycine max) & $35846 / 6.32$ & 68 & 10 & 31 & gi|42521311 \\
\hline 815 & PSII oxygen-evolving complex protein 3 (Nicotiana tabacum) & $35377 / 5.89$ & 85 & 9 & 31 & gi|505482 \\
\hline 821 & AT1G66510 (Arabidopsis thaliana) & $25242 / 6.45$ & 59 & 8 & 38 & gi|227202636 \\
\hline 822 & Hypothetical protein (Vitis vinifera) & $36723 / 8.02$ & 71 & 12 & 34 & gi|147845283 \\
\hline 822 & $\begin{array}{l}\text { Superoxide dismutase (Fe), chloroplastic; Flags: Precursor (Glycine } \\
\text { max) }\end{array}$ & $27881 / 5.60$ & 58 & 7 & 33 & gi|134646 \\
\hline 831 & cytosolic malate dehydrogenase (Glycine max) & $35846 / 6.33$ & 63 & 11 & 34 & gi|42521311 \\
\hline 833 & $\begin{array}{l}\text { Hypothetical protein SORBIDRAFT_02g031280 (Sorghum } \\
\text { bicolor) }\end{array}$ & $19264 / 4.56$ & 60 & 5 & 40 & gi|242050004 \\
\hline 847 & Conserved hypothetical protein (Ricinus communis) & $37517 / 7.64$ & 62 & 10 & 31 & gi|223507406 \\
\hline 854 & Rubisco small subunit rbcS2 (Glycine max) & $20220 / 8.87$ & 91 & 6 & 28 & gi|10946377 \\
\hline 858 & Rubisco small chain 4, chloroplast precursor (Glycine max) & $20232 / 8.87$ & 301 & 6 & 26 & gi|132113 \\
\hline 873 & Unnamed protein product (Vitis vinifera) & $29280 / 6.06$ & 101 & 17 & 39 & gi|157335145 \\
\hline 877 & Rubisco small subunit rbcS2 (Glycine max) & $20220 / 8.87$ & 175 & 15 & 57 & gi|10946377 \\
\hline 878 & $\begin{array}{l}\text { Ribulose-1,5-bisphosphate carboxylase small subunit rbcS1 } \\
\text { (Glycine } \max \text { ) }\end{array}$ & $20220 / 8.87$ & 108 & 11 & 58 & gi|10946375 \\
\hline 878 & Chain A, Wild-Type Pea Fnr & $35060 / 6.54$ & 84 & 15 & 44 & gi|4930123 \\
\hline 885 & $\begin{array}{l}\text { Hypothetical protein SORBIDRAFT_05g010323 (Sorghum } \\
\text { bicolor) }\end{array}$ & $46371 / 8.99$ & 60 & 12 & 34 & gi|242068295 \\
\hline 886 & $\begin{array}{l}\text { Superoxide dismutase (Fe), chloroplastic; Flags: Precursor (Glycine } \\
\max \text { ) }\end{array}$ & $27881 / 5.60$ & 69 & 9 & 35 & gi|134646 \\
\hline 887 & Conserved hypothetical protein (Ricinus communis) & $9604 / 5.49$ & 73 & 7 & 61 & gi|223536954 \\
\hline 890 & Conserved hypothetical protein (Ricinus communis) & $37517 / 7.64$ & 66 & 10 & 29 & gi|223507406 \\
\hline 892 & Annexin, putative (Ricinus communis) & $36405 / 6.81$ & 59 & 10 & 40 & gi|223546996 \\
\hline 896 & Conserved hypothetical protein (Ricinus communis) & $123963 / 8.64$ & 70 & 13 & 13 & gi|223527844 \\
\hline 906 & $\begin{array}{l}\text { Hypothetical protein MtrDRAFT_AC149204g22v2 (Medicago } \\
\text { truncatula) }\end{array}$ & $11312 / 7.82$ & 57 & 4 & 30 & gi|124359573 \\
\hline 907 & R2R3-MYB transcription factor (Arabidopsis thaliana) & $5365 / 10.15$ & 63 & 5 & 95 & gi|2832490 \\
\hline 916 & Unknown (Zea mays) & $46413 / 8.48$ & 53 & 8 & 21 & gi|224029795 \\
\hline 919 & Predicted protein (Micromonas sp. RCC299) & $164898 / 5.23$ & 64 & 22 & 16 & gi|226517782 \\
\hline
\end{tabular}


Table 1 (cont.)

\begin{tabular}{|c|c|c|c|c|c|c|}
\hline Spot \# & NCBI closest homologue & $\mathrm{MW} / \mathrm{pI}$ & MO & $\mathrm{PM}$ & $\mathrm{SC}(\%)$ & Accession number \\
\hline 925 & $\begin{array}{l}\text { Ubiquinol-cytochrome c reductase complex } 14 \mathrm{kDa} \text { protein }(Z e a \\
\text { mays) }\end{array}$ & $14676 / 9.78$ & 54 & 5 & 33 & gi|195627658 \\
\hline 930 & Os04g0490800 (Oryza sativa (japonica cultivar-group)) & $39811 / 6.75$ & 66 & 10 & 30 & gi|115459134 \\
\hline 945 & Hypothetical protein OsJ_14092 (Oryza sativa Japonica Group) & $12140 / 9.69$ & 56 & 7 & 58 & gi|222628516 \\
\hline 949 & Conserved hypothetical protein (Ricinus communis) & $37517 / 7.64$ & 65 & 11 & 35 & gi|223507406 \\
\hline 952 & Unknown (Zea mays) & $46413 / 8.48$ & 64 & 8 & 20 & gi|224029795 \\
\hline 953 & Conserved hypothetical protein (Ricinus communis) & $9764 / 9.3$ & 58 & 7 & 61 & gi|223549561 \\
\hline 965 & Granule-bound starch synthase I (Eragrostis advena) & $25908 / 8.52$ & 62 & 11 & 55 & gi|46326782 \\
\hline 966 & $\begin{array}{l}\text { Hypothetical protein SORBIDRAFT_04g010090 (Sorghum } \\
\text { bicolor) }\end{array}$ & $22728 / 6.07$ & 56 & 6 & 38 & gi|242064756 \\
\hline 973 & $\begin{array}{l}\text { Superoxide dismutase (Fe), chloroplastic; Flags: Precursor (Glycine } \\
\text { max) }\end{array}$ & $27881 / 5.60$ & 74 & 10 & 39 & gi|134646 \\
\hline 975 & Iron-superoxide dismutase (Glycine max) & $27506 / 5.45$ & 92 & 12 & 43 & gi|37654895 \\
\hline 979 & Maturase K (Boerhavia coccinea) & $32576 / 9.98$ & 61 & 7 & 29 & gi|15340912 \\
\hline 981 & Iron-superoxide dismutase (Glycine max) & $27506 / 5.45$ & 71 & 8 & 34 & gi|37654895 \\
\hline 996 & Predicted protein (Populus trichocarpa) & $46287 / 9.41$ & 66 & 12 & 26 & gi|224077440 \\
\hline 1003 & Predicted protein (Populus trichocarpa) & $26058 / 8.97$ & 64 & 7 & 37 & gi|224103329 \\
\hline 1014 & Iron-superoxide dismutase (Glycine max) & $27506 / 5.45$ & 77 & 10 & 37 & gi|37654895 \\
\hline 1096 & $\begin{array}{l}\text { Ubiquinol-cytochrome c reductase complex } 14 \mathrm{kDa} \text { protein (Zea } \\
\text { mays) }\end{array}$ & $14676 / 9.78$ & 59 & 7 & 43 & gi|195627658 \\
\hline 1097 & Conserved hypothetical protein (Ricinus communis) & $37517 / 7.64$ & 54 & 9 & 26 & gi|223507406 \\
\hline 1112 & Nucleoside diphosphate kinase (Glycine max) & $16402 / 6.91$ & 73 & 7 & 41 & gi|26245395 \\
\hline 1437 & ATP synthase beta subunit (Nepenthes alata) & $53059 / 5.09$ & 71 & 13 & 30 & gi $\mid 6017816$ \\
\hline 1618 & Predicted protein (Ostreococcus lucimarinus) & $84020 / 6.65$ & 63 & 10 & 16 & gi|145352412 \\
\hline 1637 & Hypothetical protein OsI_18273 (Oryza sativa Indica) & $41096 / 6.53$ & 63 & 10 & 30 & gi| 125550665 \\
\hline
\end{tabular}

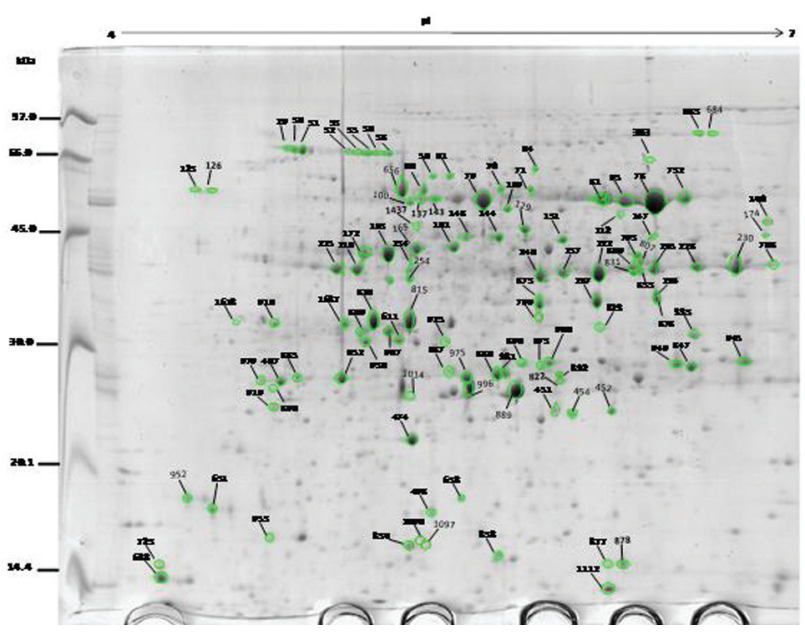

Figure 3 - Leaf proteome map indicating proteins identified by MALDITOF-MS peptide mass fingerprinting obtained from peptide fragments of trypsin digested proteins. The numbered spots indicate proteins identified and described in Table 1.

$67 \%$ means identification is significant at $\mathrm{p}<0.05$ ), while the number of peptide matches/protein identified varied between 4 and 27 (average of 11), and the sequence coverage varied between $13 \%$ and $100 \%$ (average of $35 \%$ ).

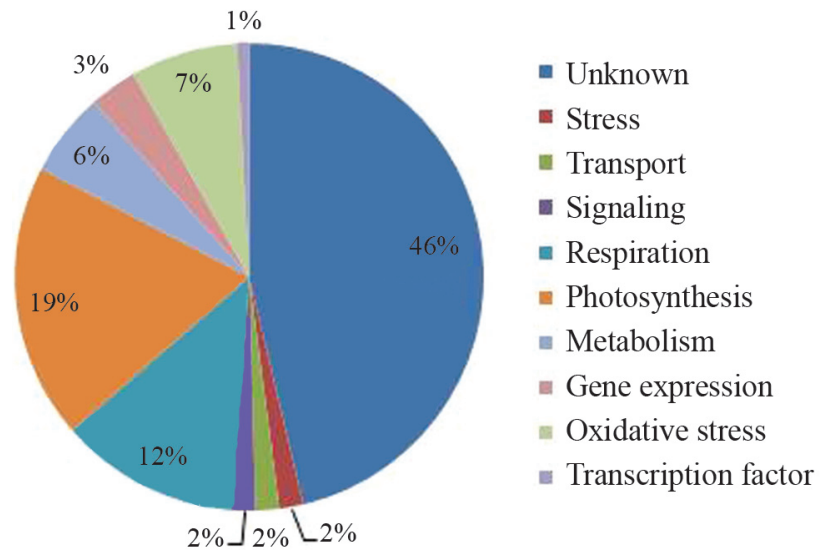

Figure 4 - Distribution of soybean leaf proteins identified using 2-DE between functional classes. The proteins used for these calculations are described in Table 1.

The functional classification of the identified proteins is presented in Figure 4. Almost 50\% of the identified proteins corresponded to proteins with unknown function, these representing the largest group. Proteins involved in primary metabolism represented the second largest group, which includes genes involved in photosynthesis, respira- 
tion and biosynthetic metabolism, the latter mainly represented by enzymes involved in amino acid biosynthesis.

The fact that a transcription factor and some proteins involved in signaling were present in the small part of the leaf proteome analyzed indicates that some low-abundance proteins could be quantified using the 2-DE method presented herein. For yeast, the most abundant proteins are present at around 2,000,000 copies per cell, which represents $4 \%$ of total protein, whereas the least abundant proteins, which likely includes transcription factors and signaling proteins (Futcher et al., 1999), are present at around 100 copies per cell (a difference of four orders of magnitude). Low-abundance proteins are generally considered difficult or even impossible to detect using 2-D gel electrophoresis (Görg et al., 2004; Krishnan and Natarajan, 2009), while genes of unknown function typically encode low-abundance proteins. Taken together, these facts are indicative that the modifications made to the TCA/acetone method allow increased detection of proteins expressed at low levels. This in turn can be partially explained by both increases in protein solubility. Based on published results and those available in the Soybean Proteomic Database that describe soybean leaf proteins (Krishnan and Natarajan, 2009; Sakata et al., 2009; Ahsan et al., 2010), we were able to add 72 new proteins to the soybean 2-DE profile, the majority of these being proteins of low abundance.

\section{Acknowledgments}

We would like to thank Dr. Thomas Christopher Rhys Williams for critical reading of the manuscript, and CNPq for financial support of the Genosoja network project.

\section{References}

Ahsan N, Donnart T, Nouri MZ and Komatsu S (2010) Tissue-specific defense and thermo-adaptive mechanisms of soybean seedlings under heat stress revealed by proteomic approach. J Proteome Res 9:4189-4204.

Arai Y, Hayashi M and Nishimura M (2008) Proteomic analysis of highly purified peroxisomes from etiolated soybean cotyledons. Plant Cell Physiol 49:526-539.

Brechenmacher L, Lee J, Sachdev S, Song Z, Nguyen TH, Joshi T, Oehrle N, Libault M, Mooney B, Xu D et al. (2009) Establishment of a protein reference map for soybean root hair cells. Plant Physiol 149:670-682.

Bradford MM (1976) A rapid and sensitive method for the quantitation of microgram quantities of protein utilizing the principle of dye binding. Anal Biochem 72:248-254.

Cho JH, Hwang H, Cho MH, Kwon YK, Jeon JS, Bhoo SH and Hahn TR (2008) The effect of DTT in protein preparations for proteomic analysis: Removal of a highly abundant plant enzyme, ribulose bisphosphate carboxylase/oxygenase. J Plant Biol 51:297-301.

Corthalis GL, Wasinger VC, Hochstrasser DF and Sanchez JC (2000) The dynamic range of protein expression: A challenge for proteomic research. Electrophoresis 21:11041115 .
Djordjevic MA, Oakes M, Li DX, Hwang CH, Hocart $\mathrm{CH}$ and Gresshoff PM (2007) The glycine max xylem sap and apoplast proteome. J Proteome Res 6:3771-3779.

Feller U, Anders I and Mae T (2008) Rubiscolytics: Fate of Rubisco after its enzymatic function in a cell is terminated. $\mathrm{J}$ Exp Bot 59:1615-1624.

Futcher B, Latter GI, Monardo P, McLaughlin CS and Garrels JI (1999) A sampling of the yeast proteome. Mol Cell Biol 19:7357-7368.

Görg A, Weiss W and Dunn MJ (2004) Current two-dimensional electrophoresis technology for proteomics. Proteomics 4:3665-3885.

Hajduch M, Ganapathy A, Stein JW and Thelen JJ (2005) A systematic proteomic study of seed filling in soybean: Establishment of high-resolution two-dimensional reference maps, expression profiles, and an interactive proteome database. Plant Physiol 137:1397-1419.

Herbert BR, Harry JL, Packer NH, Gooley AA, Pedersen SK and William KL (2001) What place for polyacrylamide in proteomics? Trends Biotechnol 19:S3-S9.

Herman EM, Helm RM, Jung R and Kinney AJ (2003) Genetic modification removes an immunodominant allergen from soybean. Plant Physiol 132:36-43.

Komatsu S, Kobayashi Y, Nishizawa K, Nanjo Y and Furukawa K (2010) Comparative proteomics analysis of differentially expressed proteins in soybean cell wall during flooding stress. Amino Acids 39:1435-1449.

Komatsu S, Yamamoto A, Nakamura T, Nouri MZ, Nanjo Y, Nishizawa K and Furukawa K (2011) Comprehensive analysis of mitochondria in roots and hypocotyls of soybean under flooding stress using proteomics and metabolomics techniques. Proteome Res 10:3993-4004.

Krishnan HB and Natarajan SS (2009) A rapid method for depletion of Rubisco from soybean (Glycine max) leaf for proteomic analysis of lower abundance proteins. Phytochemistry 70:1958-1964.

Laemmli U (1970) Cleavage of structural proteins during the assembly of the head of the bacteriophage T4. Nature 227:680-685.

Mooney BP, Krishnan HB and Thelen JJ (2004) High-throughput peptide mass fingerprinting of soybean seed proteins: Automated workflow and utility of UniGene expressed sequence tag databases for protein identification. Phytochemistry 65:1733-1744.

Nanjo Y, Skultety L, Ashraf Y and Komatsu S (2010) Comparative proteomic analysis of early-stage soybean seedlings responses to flooding by using gel and gel-free techniques. $\mathrm{J}$ Proteome Res 9:3989-4002.

Natarajan S, Xu C, Caperna TJ and Garrett WM (2005) Comparison of protein solubilization methods suitable for proteomic analysis of soybean seed proteins. Anal Biochem 342:214220.

Natarajan SS, Xu C, Bae H, Caperna TJ and Garrett WM (2006) Characterization of storage proteins in wild (Glycine soja) and cultivated (Glycine max) soybean seeds using proteomic analysis. J Agric Food Chem 54:3114-3120.

Newsholme SJ, Maleeft BF, Steiner S, Anderson NL and Schwartz LW (2000) Two-dimensional electrophoresis of liver proteins: Characterization of a drug-induced hepatomegaly in rats. Electrophoresis 21:2122-2128. 
Oehrle NW, Sarma AD, Waters JK and Emerich DW (2008) Proteomic analysis of soybean nodule cytosol. Phytochemistry 69:2426-2438.

Perkins DN, Pappin DJC, Creasy DM and Cottrell JS (1999) Probability-based protein identification by searching sequence databases using mass spectrometry data. Electrophoresis 20:3551-3567.

Rose JK, Bashir S, Giovannoni JJ, Jahn MM and Saravanan RS (2004) Tackling the plant proteome: Practical approaches, hurdles and experimental tools. Plant J 39:715-733.

Sakata K, Ohyanagi H, Nobori H, Nakamura T, Hashiguchi A, Nanjo Y, Mikami Y, Yunokawa H and Komatsu S (2009) Soybean Proteome Database: A data resource for plant differential omics. J Proteome Res 8:3539-3548.

Shaw MM and Riederer BM (2003) Sample preparation for twodimensional gel electrophoresis. Proteomics 3:1408-1417.

Shen S, Matsubae M, Takao T, Tanaka N and Komatsu S (2002) A proteomic analysis of leaf sheaths from rice. $\mathrm{J}$ Biochem 132:613-620.

Wan J, Torres M, Ganapathy A, Thelen J, Dague BB, Mooney B, $\mathrm{Xu}$ D and Stacey G (2005) Proteomic analysis of soybean root hairs after infection by Bradyrhizobium japonicum. Mol Plant Microbe Interact 18:458-467.
Wang W, Scali M, Vignani R, Spadafora A, Sensi E, Mazzuca S and Cresti M (2003) Protein for two-dimensional electrophoresis from olive leaf, a plant tissue containing hight levels of interfering compounds. Electrophoresis 24:23692375.

Zhang YM, Zhao JM, Xiang Y, Bian XC, Zuo QM, Shen Q, Gai JY and Xing H (2011) Proteomics study of changes in soybean lines resistant and sensitive to Phytophthora soja. Proteome Sci 9:52-59.

Xi J, Wang X, Li S, Zhou X, Yue L, Fan J and Hao D (2006) Polyethylene glycol fractionation improved detection of lowabundant proteins by two-dimensional electrophoresis analysis of plant proteome. Phytochemistry 67:2341-2348.

\section{Internet Resources}

Soybean Database, http://proteome.dc.affrc.go.jp/Soybean/ (accessed January 10, 2010).

License information: This is an open-access article distributed under the terms of the Creative Commons Attribution License, which permits unrestricted use, distribution, and reproduction in any medium, provided the original work is properly cited. 